\title{
Intra- and interspecific variability in prey size and niche breadth of myctophiform fish larvae
}

\author{
Ana Sabatés*, Enric Saiz \\ Institut de Ciències del Mar, CSIC, Pl. del Mar s/n, 08039 Barcelona, Catalonia, Spain
}

\begin{abstract}
Prey size is one of the major factors involved in prey selection of fish larvae, and is closely related to their foraging abilities and mouth size. This study examines the feeding habits of 6 coexisting fish larvae species of the order Myctophiformes in the western Mediterranean. The Myctophiformes are the dominant teleosts of the open oceans worldwide, and their larvae are characterized by high morphological variability. In the present study, size of ingested prey increased through larval development for all species examined, but at different rates. Niche breadth (i.e. range of sizes of ingested prey, estimated as the standard deviation of log-transformed prey sizes) was constant throughout growth. The larvae actively selected certain prey sizes; selection changed during development, and varied between species. This variability appears to be related to interspecific morphological differences, and may constitute a strategy to optimize the utilization of trophic resources in the oligotrophic open-ocean habitat.
\end{abstract}

KEY WORDS: Fish larvae $\cdot$ Myctophiformes $\cdot$ Prey size $\cdot$ Niche breadth $\cdot$ NW Mediterranean

\section{INTRODUCTION}

Most fish larvae are visual particulate feeders (Greene 1985), able to feed selectively on prey. Although factors such as prey colour and swimming behaviour can be important in determining prey perception and recognition (Checkley 1982, Govoni et al. 1986), prey size is probably the major determinant of selectivity, and this is intimately related to the mouth size of fish larvae (Shirota 1970, Hunter 1981). Accordingly, the feeding success of fish larvae should be affected by the size composition of the prey in their habitat. Studies on foraging patterns and the diet of multi-specific natural assemblages of fish larvae have indicated that the degree of prey-overlap can vary (e.g. Govoni et al. 1983, Jenkins 1987, Fortier \& Harris 1989, Economu 1991, Gaughan \& Potter 1997). Because of the high degree of morphological and behavioural variability in fish larvae, it would seem reasonable to assume that interspecific differences would have an adaptive value for the fitness of the larvae under the environmental conditions of their particular habitat.

*E-mail: anas@icm.csic.es
During ontogeny, mouth size and prey-searching ability of fish larvae increase; larger (= older) larvae are stronger swimmers and can see potential prey at greater distances than smaller (younger) stages. These ontogenetic changes are paralleled by increasing mean prey size (e.g. Shirota 1970, Arthur 1976). Pearre (1986) analyzed multi-specific data comprising various-sized fish larvae and juveniles and their prey, and concluded that niche breadth (defined as the range of sizes of ingested prey, as a log-transformed ratio) remains constant during growth. Similar results were obtained by Munk $(1992,1997)$, who found constant niche breadth and preferred prey sizes in larval herring and cod. In contrast, Pepin \& Penney (1997) concluded that prey-niche breadth increased through development in 6 of 11 species of fish larvae from the NW Atlantic, and questioned the validity of previous results reported by Shirota (1970) and Pearre (1986) because of the mixture of data sources in their studies (and consequent 'noise'). Pepin \& Penney stressed the need for conducting further interspecific studies under identical sampling and processing protocols in order to define general patterns in larval feeding ecology. 
Myctophiform larvae are the most variable and interesting of teleost larvae because of their high diversity of morphological traits (Moser 1981). Their body shape can vary from slender to robust. There are interspecific differences in eye morphology and size, and some genera have eyestalks. The adults of this order are typically mesopelagic, and the family Myctophidae comprises the highest number of genera and species, as evidenced by their ubiquitous presence in the World Ocean (Paxton 1972). In the Catalan Sea (western Mediterranean), several studies have recorded a high abundance of larvae of mesopelagic fish in the open ocean (Sabatés \& Masó 1990, Sabatés \& Olivar 1996), in accordance with the high abundance of adults in these waters (Goodyear et al. 1972).

This study describes the foraging patterns of larvae of 6 coexisting fish species (order Myctophiforme), in an open-ocean community in the Catalan Sea. The study was conducted in a small area over a short time scale (1 wk) in order to reduce potential sources of variability not related to fish-larvae behaviour. Our ultimate goal was to determine patterns in mean prey size, prey selectivity and niche breadth of the larvae, and to relate these to morphological traits.

\section{MATERIALS AND METHODS}

Sample collection and processing. The research constitutes part of a wider study on mesoscale features of plankton distribution in the Catalan Sea (western Mediterranean). Data were collected during Cruise FRONTS '95 of the RV 'García del Cid' between 18 and 23 June 1995 in an area $\left(40^{\circ} 55^{\prime} \mathrm{N}, 2^{\circ} 40^{\prime} \mathrm{E}\right)$ including stations located at the shelfbreak (1000 $\mathrm{m}$ depth; 4 visits) and in the open ocean (2000 m depth; 6 visits). All stations were sampled during the daytime; preliminary analysis of night samples revealed that all fish larvae had empty guts. Further details of the cruise can be found in Saiz et al. (1999).

Fish larvae were collected with a Bongo net $(60 \mathrm{~cm}$ mouth diam., $500 \mu \mathrm{m}$ mesh) provided with a flowmeter and towed obliquely from $200 \mathrm{~m}$ to the surface. As fish larvae are visual feeders and feed in the upper layers, the availability of microzooplankton as potential food was estimated from vertical tows from $100 \mathrm{~m}$ to the surface with a $40 \mathrm{~cm}$ diam. plankton net fitted with $53 \mu \mathrm{m}$ mesh and a flowmeter. All samples were preserved in $7 \%$ formaldehyde buffered with borax, and the volume of water filtered was estimated from the flowmeter counts.

All fish larvae were sorted out from the Bongo samples. The bulk of these corresponded to mesopelagic species from the families Myctophidae (Benthosema glaciale, Ceratoscopelus maderensis, Hygophum beno- iti, Lampanyctus crocodilus and Myctophum punctatum) and Paralepididae (Notolepis rissoi); both families belong to the order Myctophiformes. Gut-content analysis was conducted on these species. Prior to dissection, body length, upper jaw length and mouth width of the larvae were determined. Body length was measured (to the nearest $0.1 \mathrm{~mm}$ ) from the tip of the snout to the end of the notochord in preflexion and flexion larvae, and from the tip of the snout to the posterior margin of the hypural plate in postflexion larvae. Upper jaw length was measured (to the nearest $0.01 \mathrm{~mm}$ ) from the tip of the snout to the posterior end of the maxilla. Mouth width was determined (to the nearest $0.01 \mathrm{~mm}$ ), in the ventral view, as the width between the posterior edge of the maxillae; however, it could not be measured in all larvae because the measurement was unreliable when the state of preservation of the larvae was not optimum. The gut contents of a maximum of 40 individuals per species and sample were analysed (560 larvae in total). The digestive tract, including stomach and gut, was dissected with fine needles, and prey items were identified and counted, and their maximum width (hereafter, 'prey size') was measured to the nearest $0.01 \mathrm{~mm}$.

For microzooplanton samples, aliquots were prepared for counting and sizing under a stereomicroscope. The width of more than 300 nauplii and copepodites were measured per sample with the aid of an ocular micrometer.

Statistics. The relationships between body length, jaw length and mouth width of the larvae were determined by linear regression analysis. Preliminary analysis (see 'Results') indicated that mouth width did not discriminate very well between species, and consequently further analyses were conducted using only jaw length to estimate mouth size.

Regression analysis could not be applied to determine the relationship between the number of prey in the larval gut and larval size because most larvae contained only 1, 2 or 3 prey items, and larger classes were rare. Instead, larvae with full guts were classified into those containing 1 prey item and those containing $>1$ item; differences in size between the 2 groups were tested by ANOVA.

Both intraspecific and interspecific changes in the range of prey sizes ingested during larval development were determined. In the first case, the fish larvae of any 1 species were classified according to jaw length in $40 \mu \mathrm{m}$ classes. Only classes with $>1$ prey item were used for further analysis. The average and standard deviation of $\log _{10}$-transformed prey width were calculated for each class (when available). The relationships between the average jaw length of each class and the corresponding average and standard deviation of $\log _{10}$-transformed prey size were examined by linear 
regression analysis weighted with the number of prey items in each class. The standard deviation of $\log _{10^{-}}$ transformed prey size was taken as estimator of the breadth of the prey-size niche. Standard deviations were corrected for sample-size bias according to Sokal \& Rohlf (1981). To examine interspecific differences, the average of the standard deviations on $\log _{10}$ prey size were compared between species as a function of their corresponding mouth: body-size ratios.

Prey size selectivity (i.e. the presence in the gut of prey item sizes in higher or lower proportions than would be expected from their relative abundance in the field) was estimated by Chesson's index of selectivity $\alpha$ (Chesson 1978):

$$
\alpha_{k}=\frac{r_{k} / p_{k}}{\sum_{i}^{n} r_{i} / p_{i}}
$$

where $r_{k}$ and $p_{k}=$ proportion of prey size-class $k$ in larval gut and in the field respectively, and $n=$ number of prey size-classes. Neutral selection would result in a constant $\alpha_{i}=1 / n$. Although this index must be considered qualitative because of its asymmetry and lack of testability ( $\alpha$ ranges between 0 , when 1 size class has not been eaten, and 1, when only 1 class has been eaten), it was chosen for its advantage of being independent of prey density (Pearre 1982). As $88 \%$ of the identified prey were copepod nauplii and copepodites, the analysis focused only on these prey items to ensure replicability. Prey-size data was transformed logarithmically and binned in 0.1 intervals ( 9 size-classes, from $\leq 1.8$ to $>2.5$ ). The index of selectivity was calculated for each individual larvae and averaged for the preand post-flexion larvae collected at each station. In the case of Notolepis rissoi, all larvae were pre-flexion, and an arbitrary cut-off of $9 \mathrm{~mm}$ was chosen. For each larval category, a grand mean for the whole study was obtained by averaging the value for each station after weighting the data with the respective number of larvae.

\section{RESULTS}

The abundance of microzooplankton (composed mainly of copepod nauplii and copepodites) during the study ranged between 3669 and 17284 individuals $\mathrm{m}^{-3}$. The integrated concentration ( 0 to $200 \mathrm{~m}$ ) of the 6 fish-larvae species ranged between 53 and 176 larvae $\mathrm{m}^{-2}$.

The various species of fish larvae studied displayedconspicuous morphological differences (Fig. 1) that were reflected in the allometric relationship between body and mouth size. As descriptors of mouth size we initially chose jaw length and mouth width, which were well cor-
A

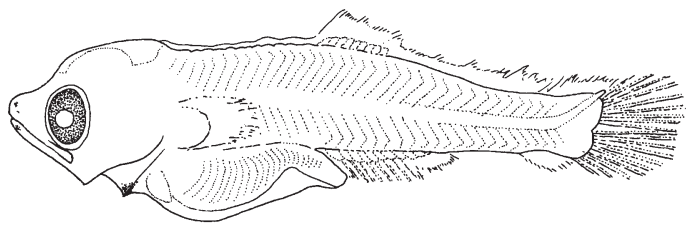

B

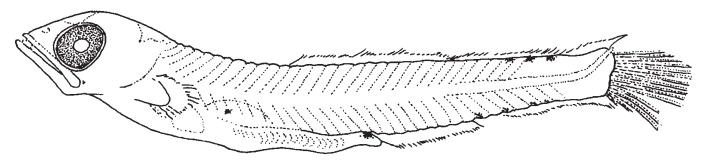

C

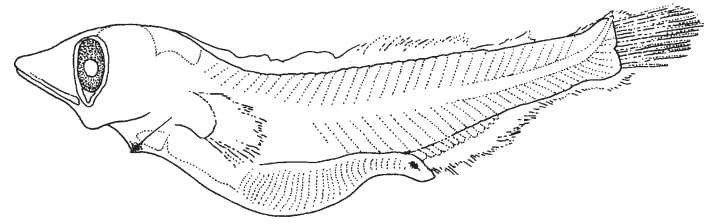

D

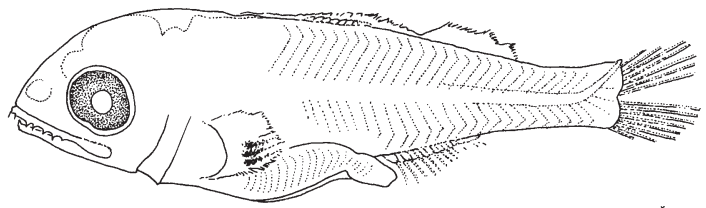

E

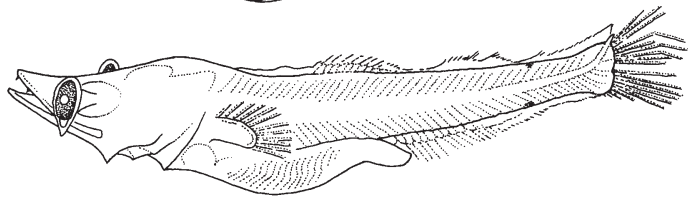

$\mathbf{F}$

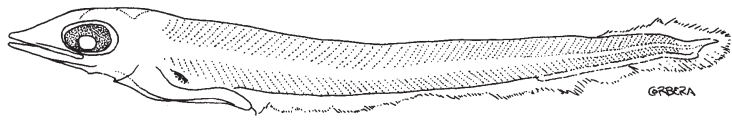

Fig. 1. Myctophiform larvae collected from the Catalan Sea during study. (A) Benthosema glaciale, $6.16 \mathrm{~mm}$; (B) Ceratoscopelus maderensis, $6.36 \mathrm{~mm}$; (C) Hygophum benoiti, $6.48 \mathrm{~mm}$; (D) Lampanyctus crocodilus, $6.48 \mathrm{~mm}$; (E) Myctophum punctatum, $8.16 \mathrm{~mm}$; (F) Notolepis rissoi, $13.02 \mathrm{~mm}$. $(\mathrm{F})=$ pre-flexion larva; all others $=$ post-flexion larvae

related (Fig. 2). Table 1 shows the predicted jaw lengths and mouth widths for fish larvae of given size. Lampanyctus crocodilus and Myctophum punctatum had the largest jaw length relative to body size (14 and $17 \%$ of body size, respectively), and also wide mouths; at the other extreme, Ceratoscopelus maderensis and Notolepis rissoi had the smallest jaw length relative to body size ( 8 and $7 \%$, respectively) and also the smallest relative mouths. As jaw length varied more between species of a given size than mouth width and seemed to discriminate better between them (Table 1), we use only jaw length as descriptor of mouth size in further analyses. Hereafter, 'mouth size' will refer to jaw length, unless otherwise specified.

The magnitude of the increases in mouth size (jaw length) during development (i.e. the slope of the bodymouth-size relationship), differed between species 
Table 1. Myctophiform larvae. Predicted jaw length and mouth width for larvae of given sizes. Predictions based on regression equations in Figs. 2 \& 3. (As Ceratoscopelus maderensis larvae do not attain a body size of $10000 \mu \mathrm{m}$, no predictions were made for this species)

\begin{tabular}{|c|c|c|c|c|c|c|}
\hline \multirow[t]{2}{*}{ Prey species } & \multicolumn{2}{|c|}{ Body size: $5000 \mu \mathrm{m}$} & \multicolumn{2}{|c|}{ Body size: $8000 \mu \mathrm{m}$} & \multicolumn{2}{|c|}{ Body size: $10000 \mu \mathrm{m}$} \\
\hline & $\begin{array}{c}\text { Jaw length } \\
(\mu \mathrm{m})\end{array}$ & $\begin{array}{c}\text { Mouth width } \\
(\mu \mathrm{m})\end{array}$ & $\begin{array}{c}\text { Jaw length } \\
(\mu \mathrm{m})\end{array}$ & $\begin{array}{c}\text { Mouth width } \\
(\mu \mathrm{m})\end{array}$ & $\begin{array}{c}\text { Jaw length } \\
(\mu \mathrm{m})\end{array}$ & $\begin{array}{l}\text { Mouth width } \\
(\mu \mathrm{m})\end{array}$ \\
\hline Benthosema glaciale & 561 & 404 & 1104 & 789 & 1466 & 1045 \\
\hline Ceratoscopelus maderensis & 377 & 301 & 749 & 491 & - & - \\
\hline Hygophum benoiti & 421 & 338 & 994 & 717 & 1376 & 970 \\
\hline Lampanyctus crocodilus & 656 & 356 & 1400 & 677 & 1896 & 891 \\
\hline Myctophum punctatum & 587 & 494 & 1385 & 825 & 1917 & 1046 \\
\hline Notolepis rissoi & 380 & 364 & 572 & 424 & 700 & 463 \\
\hline
\end{tabular}
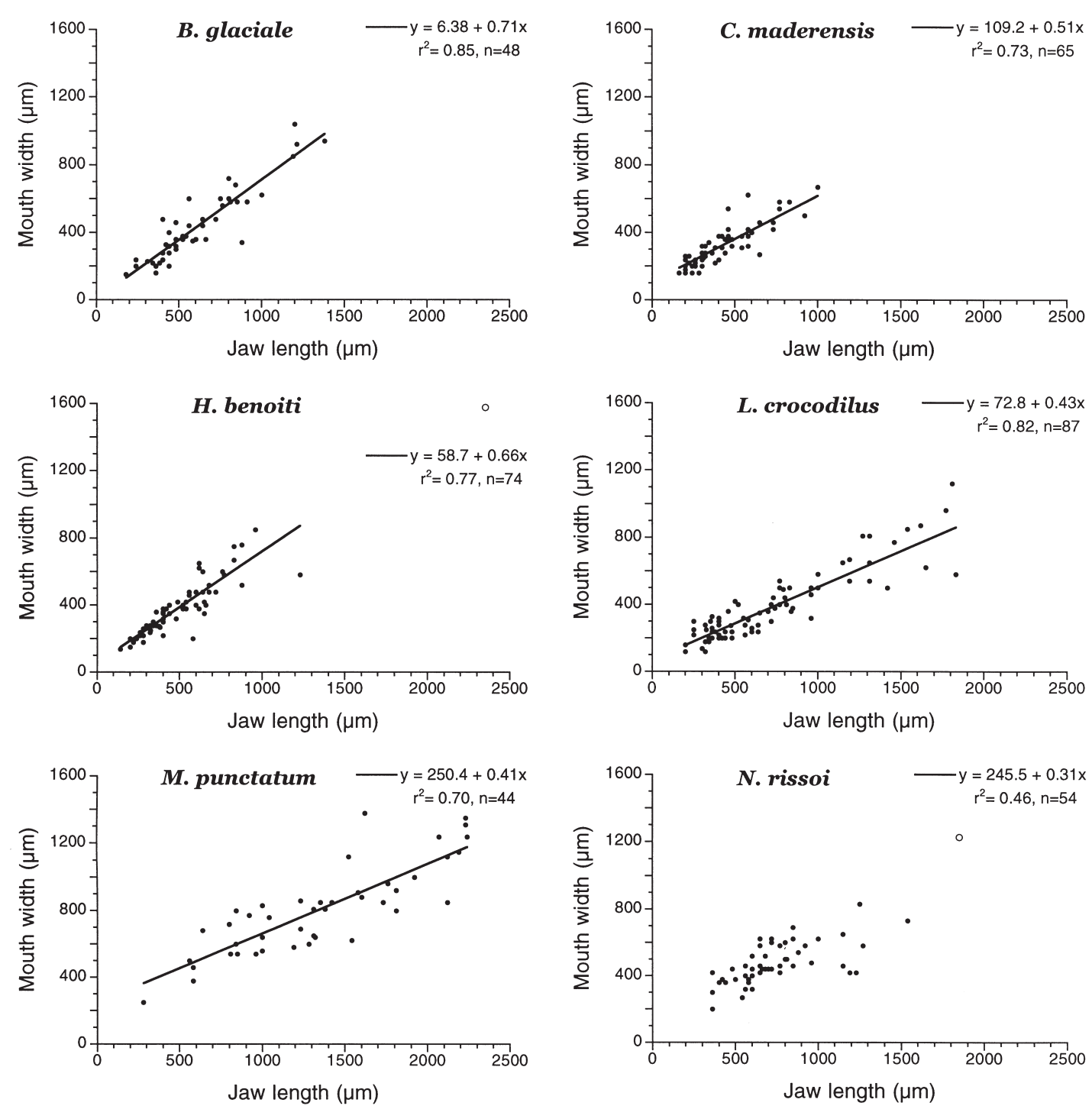

Fig. 2. Myctophiform larvae. Relationship between jaw length and mouth width for 6 species studied. $\circ=$ data not used in regression analysis. Full species names in Table 1 

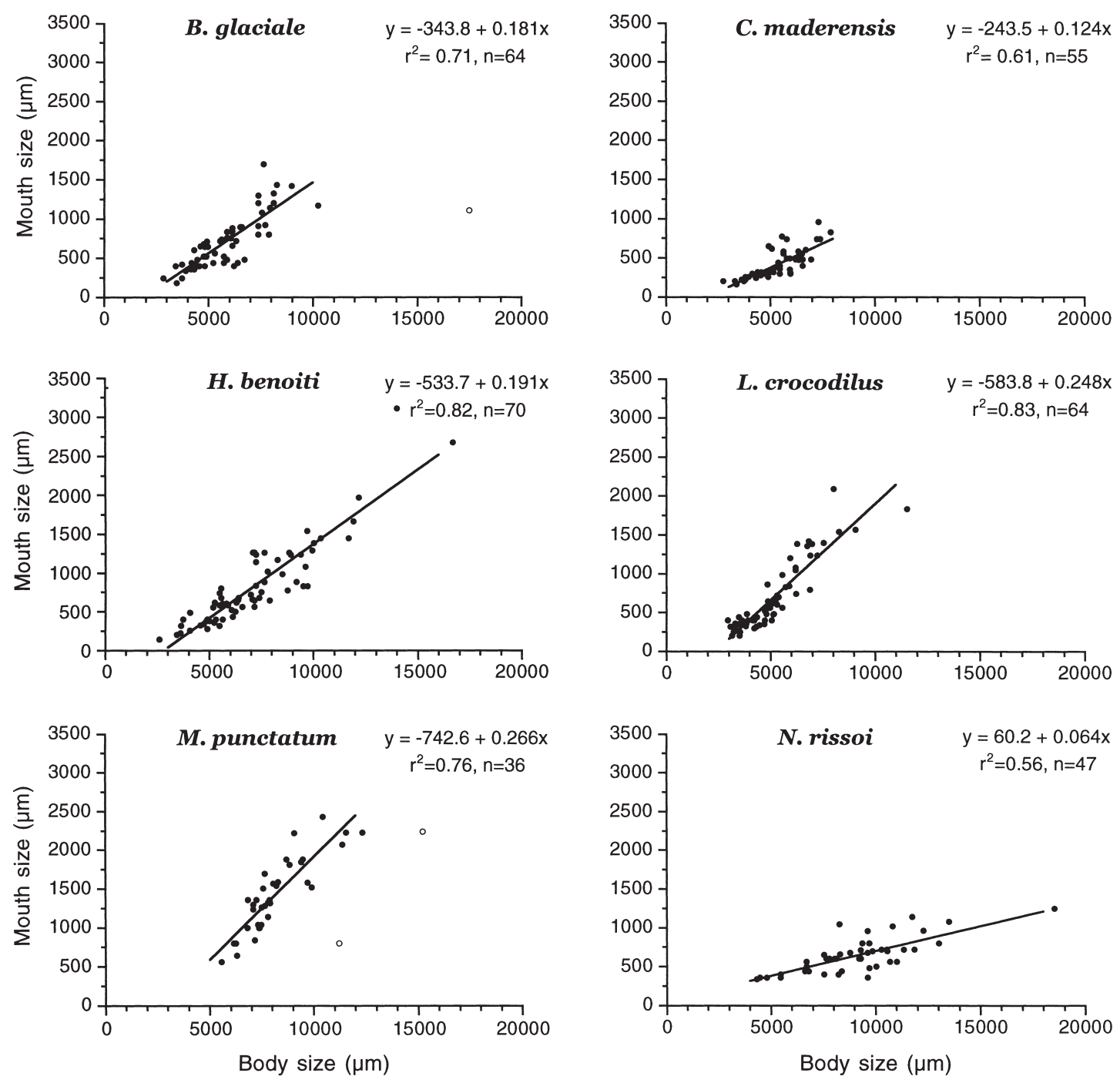

Fig. 3. Myctophiform larvae. Relationship between body size and mouth size for 6 species studied. $\circ=$ data not used in regression analysis

(Fig. 3), being highest in Lampanyctus crocodilus and Myctophum punctatum, and lowest in Notolepis rissoi.

The gut-contents analysis revealed the most abundant prey items to be copepod nauplii and copepodites. Although the relative contribution of nauplii and copepodite prey varied between species, in the pre-flexion larval stages copepod nauplii were the dominant prey (nauplii accounted for $60 \%$ of prey, copepodites for $29 \%$ ), while post-flexion stages contained a higher proportion of copepodites ( $27 \%$ nauplii, $61 \%$ copepodites).

In general, in all species, the number of prey items in the gut tended to increase with increasing larval size (Table 2). Hygophum benoiti, Myctophum punctatum and Notolepis rissoi displayed marked differences in prey frequency as a function of body size, although the differences were only weakly significant for $M$. punctatum. Only $H$. benoiti and $M$. punctatum displayed significant differences in mouth size; the lack of difference in $N$. rissoi may be related to the particular allometric development of mouth and body size of this species.

In all species, prey size increased during larval development (Fig. 4), and comprised a fairly constant percentage of mouth size (average $=17$ to $22 \%$ ), except in Myctophum punctatum, which captured relatively smaller prey $(13 \%)$.

The rate of change in prey size with increasing larval development (i.e. the slope of the prey size/mouth size relationship) differed widely between species (Table 3), 

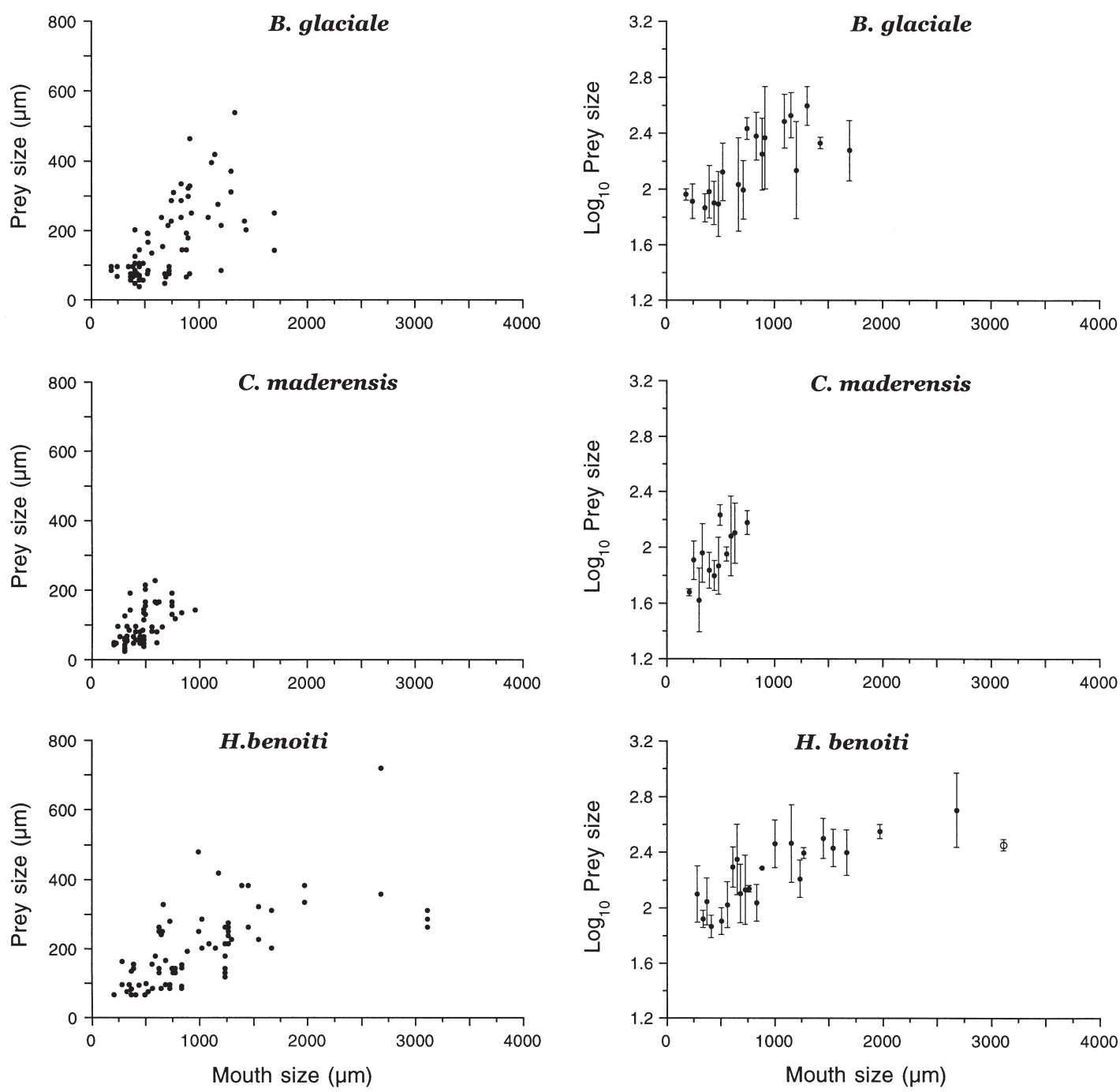

Fig. 4. (Above and facing page.) Myctophiform larvae. Prey size-mouth size relationship for 6 species studied. Left graphs show untransformed raw data; right graphs show $\log _{10}$-transformed prey width (avg. \pm SE) for predator size-classes $(40 \mu \mathrm{m})$. $\circ=$ data not used in the regression analysis

being highest for Ceratoscopelus maderensis, and lowest for Myctophum punctatum and Hygophum benoiti. It appeared to be inversely related to the mouth size:body size ratio (Fig. 5a).
Niche breadth was independent of mouth size, and did not vary during larval development (regression analysis for each species $=p>0.1$ : Table 3). Interspecific comparison revealed that niche breadth also did

Table 2. Myctophiform larvae. Mouth and body size $( \pm \mathrm{SE})$ of fish larvae, classified according to the number of prey in the gut. ${ }^{*} \mathrm{p}<0.081,{ }^{* *} \mathrm{p}<0.03,{ }^{* * *} \mathrm{p}<0.01$

\begin{tabular}{|lcccc|}
\hline \multirow{2}{*}{ Prey species } & \multicolumn{2}{c}{ Mouth size $(\mu \mathrm{m})$} & \multicolumn{2}{c|}{ Body size $(\mu \mathrm{m})$} \\
& 1 prey & $>1$ prey & 1 prey & $>1$ prey \\
\hline Benthosema glaciale & $696 \pm 54.6$ & $755 \pm 90.2$ & $5679 \pm 249.8$ & $5834 \pm 407.9$ \\
Ceratoscopelus maderensis & $468 \pm 34.3$ & $438 \pm 47.7$ & $5758 \pm 185.7$ & $5767 \pm 262.6$ \\
Hygophum benoiti & $726 \pm 83.7$ & $1118 \pm 111.5^{* * *}$ & $6526 \pm 296.2$ & $8180 \pm 418.8^{* * *}$ \\
Lampanyctus crocodilus & $659 \pm 72.2$ & $713 \pm 87.7$ & $4958 \pm 253.3$ & $5293 \pm 307.7$ \\
Myctophum punctatum & $1285 \pm 90.5$ & $1703 \pm 125.5^{* *}$ & $7876 \pm 373.7$ & $9053 \pm 538.6^{*}$ \\
Notolepis rissoi & $612 \pm 40.8$ & $689.8 \pm 48.1$ & $8092 \pm 382.1$ & $9919 \pm 472.1^{* * *}$ \\
\hline
\end{tabular}



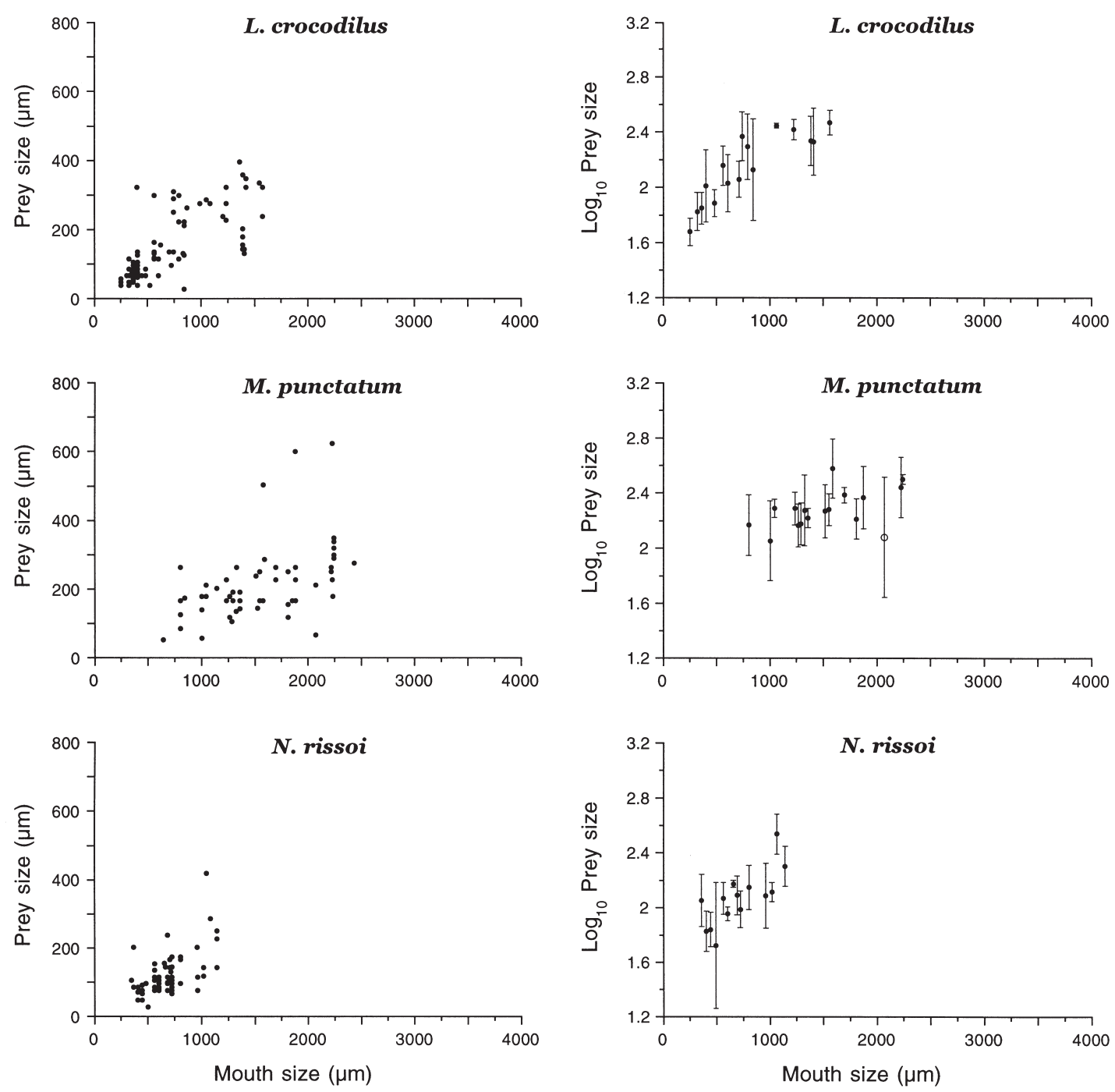

not vary among species, and that it was not related to the mouth size:body size ratio (Fig. 5b).

Chesson's index of selectivity showed that during our study fish larvae ingested some prey sizes in higher frequency than would be expected from their relative abundance in the field (cf. Figs. 6 \& 7). Preferred prey size varied between species, and in all species the size of the preferred prey shifted to larger sizes as the fish larvae grew.

\section{DISCUSSION}

As observed widely in previous studies (e.g. Last 1980, Hunter 1981, Young \& Davis 1990), in the fishlarvae species we studied the size of ingested prey increased throughout development. This pattern is obviously related to increases in speed, perceptive dis-

tance and capture efficiency with increasing larval size (Hunter 1981). It has been long speculated that this increase in prey size may be accompanied by a wider size-spectrum of captured prey (Houde 1997). This wider spectrum would enhance the survival chances of fish larvae as they grow, since it would increase their range of potentially available food. However, Pearre (1986) warned of the risk of concluding trends in foraging patterns from predator-prey size relationships based on the analysis of untransformed data sets. Thus, when data on prey size of several fish species were analyzed on a ratio-scale (using either the coefficient of variation or the standard deviation of $\log _{10}$-transformed data), a constant prey-size spectrum was found (Pearre 1986, Munk 1992, 1997). Although Pepin \& Penney (1997) showed that this constancy of niche breadth may not be universal, a similar analysis for the 6 species of Myctophiform fish larvae in our study also 

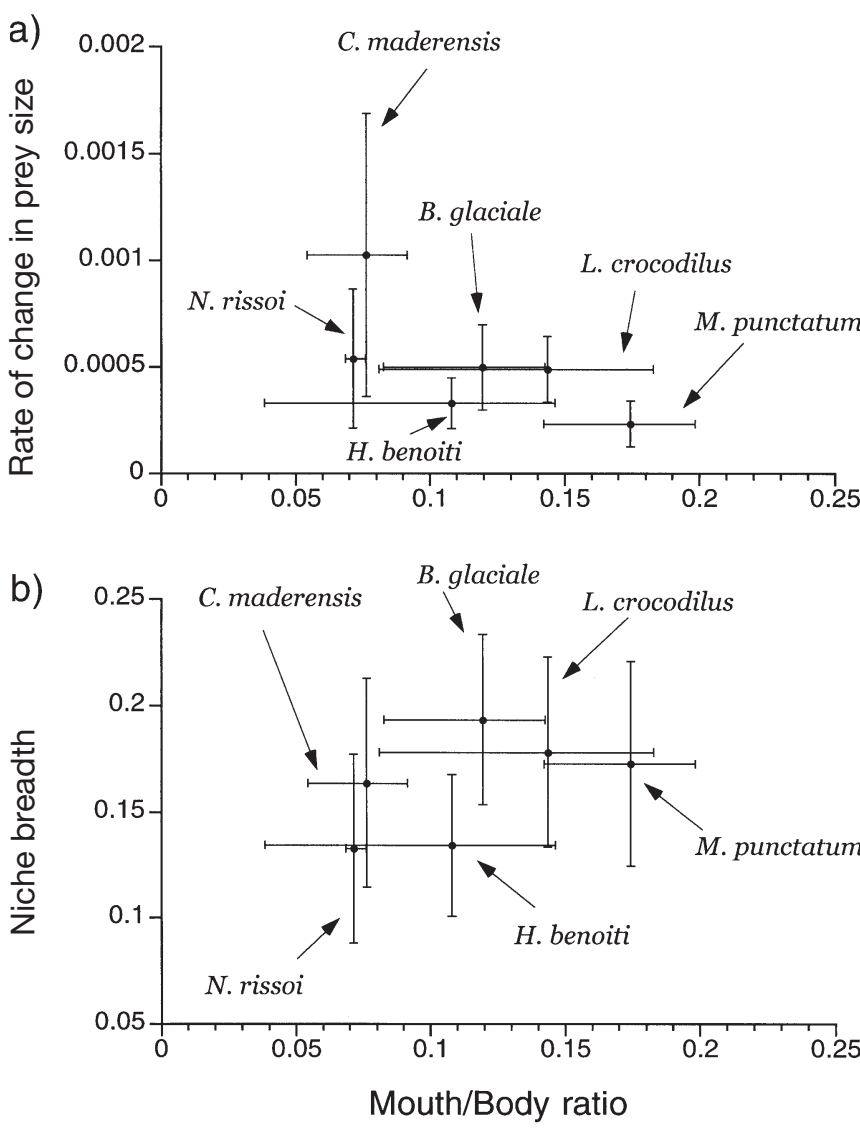

Fig. 5. Myctophiform larvae. Relationship between mouth size:body size ratio and (a) rate of change in prey size (slope of $\log _{10}$ prey size:mouth size regression) and (b) niche breadth (average of SD of $\log _{10}$ prey for each mouth-size class) for 6 species studied. Error bars for slope and niche breadth variables $=1$ SE. Mouth size:body size ratio was estimated from mouth size:body size regression lines in Fig. 3. Data are means and range

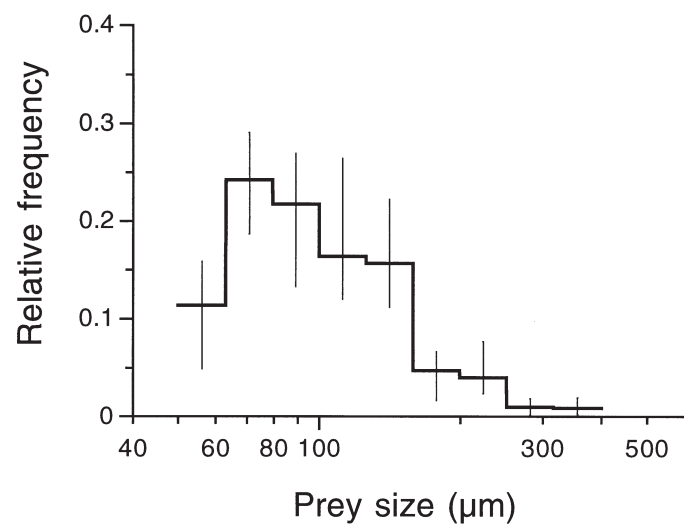

Fig. 6. Myctophiform larvae. Size spectrum (average and range, in $\log _{10}$ classes) of copepod nauplii and copepodites in field area for 9 stations sampled

revealed a constant niche breadth throughout larval development.

Despite this constancy in niche breadth, the analysis of our raw, untransformed data actually indicates a broader range of prey sizes with increasing larval size (see Fig. 4, left-hand graphs). In this respect, Houde (1997), in a recent review on fish-larvae foraging behaviour, re-analyzed Pearre's (1986) and Munk's (1992) data and concluded that although the prey-size spectrum was invariant throughout larval development on a ratio-scale, their raw data show a clear increase in the range of ingested prey size. We believe that the different conclusions reflect different points of view: In order to understand larval feeding in relation to larval energetics, feeding capabilities should be considered as a function of prey size on a ratio-scale, and test

Table 3. Myctophiform larvae. Weighted linear-regression analysis of average prey width ( $\log _{10}$-transformed) and trophic nichebreadth width (SD of $\log _{10}$-transformed data) as a function of mouth size of fish larvae. Slope, intercept, corresponding standard errors, and determination coefficient are shown. ${ }^{*} \mathrm{p}<0.01,{ }^{* *} \mathrm{p}<0.05$

\begin{tabular}{|c|c|c|c|c|c|}
\hline & Intercept & (SE) & Slope & (SE) & $r^{2}$ \\
\hline \multicolumn{6}{|c|}{ Average prey size vs larvae mouth-size } \\
\hline Benthosema glaciale & $1.78^{*}$ & $(0.075)$ & $0.00050^{*}$ & $(0.000095)$ & 0.62 \\
\hline Ceratoscopelus maderensis & $1.46^{*}$ & $(0.139)$ & $0.00102^{*}$ & $(0.000298)$ & 0.54 \\
\hline Hygophum benoiti & $1.93^{*}$ & $(0.059)$ & $0.00033^{*}$ & $(0.000057)$ & 0.62 \\
\hline Lampanyctus crocodilus & $1.76^{*}$ & $(0.057)$ & $0.00049^{*}$ & $(0.000072)$ & 0.77 \\
\hline Myctophum punctatum & $1.94^{*}$ & $(0.081)$ & $0.00023^{*}$ & $(0.000050)$ & 0.61 \\
\hline Notolepis rissoi & $1.68^{*}$ & $(0.104)$ & $0.00054^{*}$ & $(0.000150)$ & 0.52 \\
\hline \multicolumn{6}{|c|}{ Trophic niche-breadth width vs larvae mouth-size } \\
\hline Benthosema glaciale & $0.16^{*}$ & $(0.043)$ & 0.00005 & $(0.000055)$ & 0.05 \\
\hline Ceratoscopelus maderensis & $0.18^{* *}$ & $(0.077)$ & -0.00005 & $(0.000165)$ & 0.01 \\
\hline Hygophum benoiti & $0.14^{*}$ & $(0.035)$ & -0.00000 & $(0.000034)$ & 0.00 \\
\hline Lampanyctus crocodilus & $0.18^{*}$ & $(0.043)$ & 0.00000 & $(0.000054)$ & 0.00 \\
\hline Myctophum punctatum & $0.23^{*}$ & $(0.072)$ & -0.00004 & $(0.000044)$ & 0.06 \\
\hline Notolepis rissoi & 0.14 & $(0.077)$ & -0.00000 & $(0.000112)$ & 0.00 \\
\hline
\end{tabular}



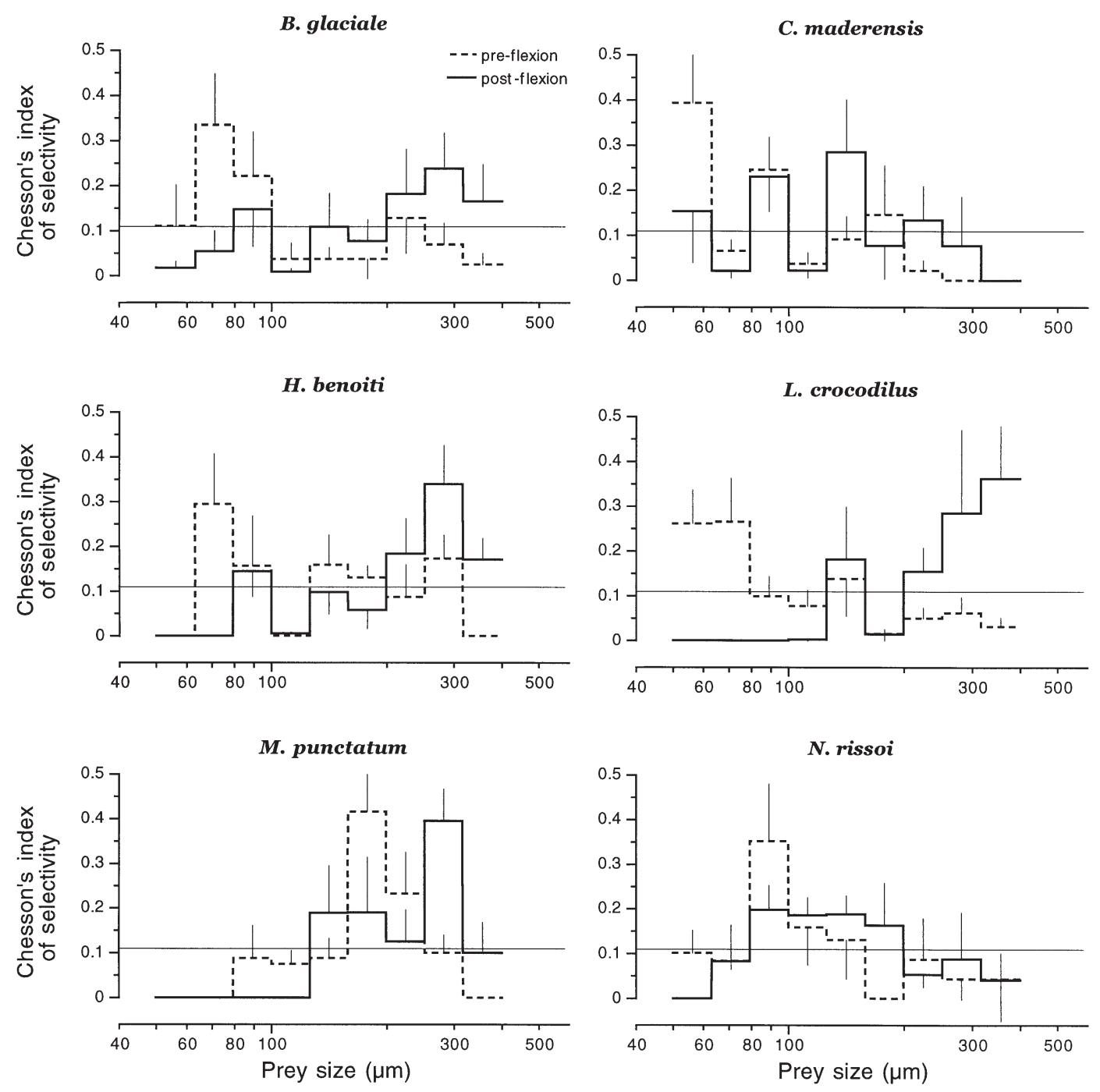

Fig. 7. Myctophiform larvae. Index of selectivity (Chesson's $\alpha$ ) of copepod nauplii and copepodites by 6 species of fish larvae studied. Dashed and continuous lines correspond, respectively, to pre- and postflexion larvae, except for Notolepis rissoi, where the lines distinguish larvae with body sizes smaller and longer than $9 \mathrm{~mm}$ (all preflexion). For the other species, the flexion of the urostyle was at $6 \mathrm{~mm}$ body length, except for Hygophum benoiti (6.3 mm), and Myctophum punctatum (7.3 mm). Data are means and SE (only 1 side shown) for all stations combined

whether or not the weight ratio largest-to-smallest prey is constant throughout development (Pearre 1986). However, from the point of view of the actual range of prey sizes ingested by fish larvae and its impact on the prey community, the prey size-spectrum broadens as the larva grows (Houde 1997).

Interpretation of interspecific differences in the rate of change in prey size throughout larval development should take into account the morphological and physiological features of the species concerned. Thus, the fact that Hygophum benoiti and Myctophum punctatum displayed the lowest rate of change in prey size as they grew ( $M$. punctatum also ingested relatively smaller prey) was compensated by increased ingestion rates, as indicated by the higher frequency of prey items found in the guts of the largest individuals. Although Notolepis rissoi displayed intermediate rate of change in prey size, the guts of the largest individuals of this species also contained more prey items The peculiar morphology of the larva of $N$. rissoi, with its elongated body and relatively small mouth size, must limit the size of its prey; very likely in order to meet its increasing metabolic requirements with increasing development, this species must rely on a higher frequency of captured prey.

Differences in the rate of change in prey size are partly related to interspecific differences in the changes in the morphology and in the swimming capa- 
bility that the fish larvae experience during development. Larvae of Lampanyctus crocodilus and Myctophum punctatum provide good examples. Both species had the highest mouth:body size-ratio (jaw length = 15 and $17 \%$ of body size, respectively; both have also wide mouths) in our study. Prey size of $L$. crocodilus larvae increased markedly during development, and they consumed relatively large prey (19\% of jaw length); these larvae are characterized by significant robustness of the body, by large-toothed jaws, and by notochord flexion at a body length of $\sim 6 \mathrm{~mm}$. In contrast, the rate of change in prey size of $M$. punctatum larvae was lower, and they consumed relatively smaller prey (13\% of jaw length); this species has a more elongated morphology and notochord flexion occurs at larger sizes, $\sim 7.8 \mathrm{~mm}$ standard length. Notochord flexion is accompanied by rapid development of the fin rays, changes in larval body shape, locomotive ability, and feeding techniques (Kendall et al. 1984). Mouth size does not seem to be the main factor limiting prey size in $M$. punctatum larvae, and other factors such as swimming, strike ability, or prey detection may be involved.

Besides variations in locomotive capabilities and motility of fish larvae, some differences observed in our study may be related to differences in visual acuity (Blaxter 1986). Among the high diversity of morphological traits that characterizes the family Myctophidae, eye shape is one of the most important. This family is divided into the sub-families Myctophinae and Lampanyctinae, which are characterized by larvae with elliptical and rounded eyes, respectively (Moser \& Ahlstrom 1970). These differences in the morphological (and probably physiological) characteristics of their eyes may have an adaptive role related to the vertical position of the larvae in the water column. Thus, the sub-family Lampanyctinae, represented in our study by the larvae of Ceratoscopelus maderensis and Lampanyctus crocodilus, occurs in superficial waters, preferentially in the upper 30 m (Olivar \& Sabatés 1997); while the sub-family Myctophinae, represented in our study by Benthosema glaciale, Hygophum benoiti and Myctophum punctatum, has a deeper distribution, generally between 25 and 75 m (John \& Ré 1995, Olivar et al. 1998). Of the 3 species of Myctophinae in our study, both $H$. benoiti and $M$. punctatum have markedly elliptic eyes (also eyestalks in the case of $M$. punctatum: see Fig. 1E), while B. glaciale's eyes are of intermediate shape. Curiously, the former 2 species had the lowest rate of change in prey size during development. There is no proof, however, that this coincidence is causal. Weihs \& Moser (1981) suggested that elliptic eyes, either sessile or with short stalks, must increase the visual field of fish larvae and consequently enable the perception of prey at longer dis- tances; they could also be an adaptation for increasing visual resolution in larvae inhabiting deeper waters.

Some of the patterns observed in predator-prey-size relationships may also be related to the vertical position of the different species in the water column and the size spectrum of the prey available at those depths. Our integrated vertical samples did not show much variation in prey size-spectrum during the study, although small-scale vertical patchiness could result in different prey size-spectra. However, our results show that the minimum and maximum prey sizes ingested were similar in all species studied, suggesting that the prey size-spectra available at different depths was similar. For instance, the narrowness of the prey sizespectrum of Ceratoscopelus maderensis is most probably due to species-specific characteristics and not to a limitation imposed by prey availability: this is supported by the fact that the prey size-spectra of Lampanyctus crocodilus, which inhabits the same depths, is much broader.

We have shown that the high morphological diversity between fish larvae of Myctophiformes species results in a high variability in their diet and feeding strategies. The larvae actively select certain prey sizes, and this selection not only changes during development but also varies between species. Consequently, the size ranges of the preferred prey covered the whole prey size-spectrum. From an adaptive point of view, and considering the high ecological success of the order Myctophiformes in the World ocean, the high morphological diversity of its larvae may be a strategy to optimize the utilization of trophic resources in the oligotrophic open-ocean habitat, and thus, contribute to survival in the early larval stages.

Acknowledgements. We are indebted to P. Philippe for her helpful assistance in the laboratory work. We thank Dr A. Calbet for his support, and all our colleagues for their assistance in the research cruise. This work was supported by Grants MAS3-CT96-0051 from the EU and AMB 94-0853 and MAR 98-0932 from the CICYT.

\section{LITERATURE CITED}

Arthur DK (1976) Food and feeding of larvae of three fishes occurring in the California Current, Sardinops sagax, Engraulis mordax, and Trachurus symmetricus. Fish Bull US 74:517-530

Blaxter JHS (1986) Development of sense organs and behavior of teleost larvae with special reference to feeding and predator avoidance. Trans Am Fish Soc 115:98-114

Checkley DM (1982) Selective feeding by Atlantic herring (Clupea harengus) larvae on zooplankton in natural assemblages. Mar Ecol Prog Ser 9:245-253

Chesson J (1978) Measuring preference in selective predation. Ecology 59:211-215

Economu AN (1991) Food and feeding ecology of five gadoid 
larvae in the northern North Sea. J Cons Int Explor Mer 47:339-351

Fortier L, Harris RP (1989) Optimal foraging and densitydependent competition in marine fish larvae. Mar Ecol Prog Ser 51:19-33

Gaughan DJ, Potter IC (1997) Analysis of diet and feeding strategies within an assemblage of estuarine larval fish and an objective assessment of dietary niche overlap. Fish Bull US 95:722-731

Goodyear RH, Zahuranec BJ, Pugh WL, Gibbs RH (1972) Ecology and vertical distribution of Mediterranean midwater fishes. Mediterr Biol Stud Final Rep 1:91-229

Govoni JJ, Hoss DE, Chester AJ (1983) Comparative feeding of three species of larval fishes in the Northern Gulf of Mexico: Brevoortia patronus, Leiostomus xanthurus, and Micropogonias undulatus. Mar Ecol Prog Ser 13:189-199

Govoni JJ, Ortner P, Al-Yamani F, Hill LC (1986) Selective feeding of spot, Leiostomus xanthurus, and Atlantic croaker, Micropogonias undulatus, larvae in the northern Gulf of Mexico. Mar Ecol Prog Ser 28:175-183

Greene CH (1985) Planktivore functional groups and patterns of prey selection in pelagic communities. J Plankton Res 7: $35-40$

Houde ED (1997) Patterns and consequences of selective processes in teleosts early life histories. In: Chambers RC, Trippel EA (eds) Early life history and recruitment in fish populations, Chapman \& Hall, London, p 173-196

Hunter JR (1981) Feeding ecology and predation of marine fish larvae. In: Lasker R (ed) Marine fish larvae: morphology, ecology and relation to fisheries. Washington Sea Grant Program, Seattle, WA, p 34-77

Jenkins GP (1987) Comparative diets, prey selection, and predatory impact of co-occurring larvae of two flounder species. J Exp Mar Biol Ecol 110:147-170

John HC, Ré P (1995) Cross-shelf zonation, vertical distribution and drift of fish larvae off northern Portugal during weak upwelling. Arq Mus Bocage (Nova Sér) 2:607-632

Kendall AW Jr, Ahlstrom EH, Moser HG (1984) Early life history stages of fishes and their characters, In: Moser HG, Richards WJ, Cohen DM, Fahay MP, Kendall AW, Richardson SL (eds) Ontogeny and systematics of fishes. American Society of Ichthyologists and Herpetologists. Allen Press Inc, Lawrence, Kansas, p 11-22 (Spec Publs Am Soc Ichthyol Herpetol No. 1)

Last JM (1980) The food of twenty species of fish larvae in the west-central North Sea. Fish Res Tech Rep Minist Agric Fish Fd, Directorate Fish Res, Lowestoft 60:1-44

Moser HG (1981) Morphological and functional aspects of marine fish larvae. In: Lasker R (ed) Marine fish larvae: morpholgy, ecology and relation to fisheries. Washington Sea Grant Program, Seattle, WA, p 89-131

Editorial responsibility: Otto Kinne (Editor),

Oldendorf/Luhe, Germany
Moser HG, Ahlstrom EH (1970) Development of lanternfishes (family Myctophidae) in the California Current. Part I. Species with narrow-eyed larvae. Sci Bull Nat Hist Mus Los Ang Cty 7:1-145

Munk P (1992) Foraging behaviour and prey size spectra of larval herring Clupea harengus. Mar Ecol Prog Ser 80: 149-158

Munk P (1997) Prey size spectra and prey availability of larval and small juvenile cod. J Fish Biol 51(Suppl A): 340-351

Olivar MP, Sabatés A (1997) Vertical distribution of fish larvae in the NW Mediterranean Sea in spring. Mar Biol 129: 289-300

Olivar MP, Sabatés A, Abelló P, García M (1998) Transitory hydrographic structures and distribution of fish larvae and neustonic crustaceans in the north-western Mediterranean. Oceanol Acta 21:95-104

Paxton JR (1972) Osteology and relationships of the lanternfishes (family Myctophidae). Sci Bull Nat Hist Mus Los Ang Cty 13:1-81

Pearre S (1982) Estimating prey preference by predators: uses of various indices, and a proposal of another based on $\chi^{2}$. Can J Fish Aquat Sci 39:914-923

Pearre S (1986) Ratio-based trophic niche breadths of fish, the Sheldon spectrum, and the size efficiency hypothesis. Mar Ecol Prog Ser 29:299-314

Pepin P, Penney RW (1997) Patterns of prey size and taxonomic composition in larval fish: are there general sizedependent models? J Fish Biol 51(Suppl A):84-100

Sabatés A, Masó M (1990) Effect of a shelf-slope front on the spatial distribution of mesopelagic fish larvae in the Western Mediterranean. Deep-Sea Res 37:1085-1098

Sabatés A, Olivar MP (1996) Variation of larval fish distributions associated with variability in the location of a shelfslope front. Mar Ecol Prog Ser 1135:11-20

Saiz E, Calbet A, Irigoien X, Alcaraz M (1999) Copepod egg production in the western Mediterranean: response to food availability in oligotrophic environments. Mar Ecol Prog Ser 187:179-189

Shirota A (1970) Studies of the mouth size of fish larvae. Bull Jpn Soc Fish Oceanogr 36:353-368

Sokal RR, Rohlf FJ (1981) Biometry. The principles and practice of statistics in biological research, 2nd edn. WH Freeman \& Co, New York

Weihs D, Moser HG (1981) Stalked eyes as an adaptation towards more efficient foraging in marine fish larvae. Bull Mar Sci 31:31-36

Young JW, Davis TLO (1990) Feeding ecology of larvae of southern bluefin, albacore and skipjack tunas (Pisces: Scombridae) in the eastern Indian Ocean. Mar Ecol Prog Ser 61:17-29

Submitted: August 2, 1999; Accepted: December 1, 1999 Proofs received from author(s): July 7, 2000 